\title{
Investment Limitation Between ASEAN and Non-ASEAN Countries in Presidential Regulation: Dimension of Non- Discrimination Principles
}

\author{
Ni Luh Putu Wulan Purwanti ${ }^{1}$
}

${ }^{1}$ Vidhi Law Office, E-mail: purwanti.wulan@ymail.com

\begin{tabular}{l}
\hline Info Article \\
\hline Received: $9^{\text {th }}$ May 2019 \\
Accepted: $12^{\text {nd }}$ July 2020 \\
Published: $31^{\text {st }}$ Juli 2020 \\
Keywords: \\
Investment Limitation; \\
ASEAN; Non-Discrimination \\
Corresponding Author: \\
Ni Luh Putu Wulan Purwanti, \\
Email: \\
purwanti.wulan@ymail.com \\
DOI: \\
10.24843/JMHU.2020.v09.i02. \\
p.02
\end{tabular}

\begin{abstract}
Indonesia is bound by TRIMs agreements in terms of investment policies regarding goods trade and GATS regarding services trade. TRIMs and GATS as annexes of WTO agreements adhere to the non-discrimination principle namely MFN and NT. The difference in the percentage of the amount of capital that allowed to be owned in several business fields for a foreign investor to the investor from ASEAN and Non-ASEAN member countries is found in President Regulation No. 44/2016. Different treatment of non-ASEAN countries in the said Presidential Regulation whether it is a breach of the non-discrimination principle. It is deemed important to be investigated to know whether the investment regulations in Indonesia for the investors from ASEAN and Non-ASEAN countries have implemented the nondiscrimination principle. Statutory and analytical of conceptual approach type in normative legal research were used in this writing. Indonesia as a developing country shall be included in the exemption by the WTO to make regulations which in this case give special treatment to ASEAN member countries as stipulated in Article 4 of the TRIMs and flexibility in implementing the nondiscrimination principle referred to in Article 4 and 5 of GATS.
\end{abstract}

\section{Introduction}

Trade between countries in the world in its development is closely related to the World Trade Organization or commonly abbreviated as WTO as an international trade organization. Indonesia in its involvement as a WTO member shall subject to agreements on world trade including TRIMs and GATS. Agreement on Trade-Related Investment Measures (TRIMs) is one of the world trade agreements on investment policies. The TRIMs agreement specifically regulates investment policies on goods only, while the service sector is regulated in more detail in the General Agreement on Trade in Services (GATS). ${ }^{1}$ WTO agreements, in their clauses and rules, adhere to the non-discrimination principle of NT (National Treatment) and MFN (Most Favored Nation) which can be found in articles 2 and 17 of GATS and article 2 of TRIMs. ${ }^{2}$ Members of WTO namely Indonesia and other member countries have the obligation

${ }^{1}$ Dharmawant, N. K. S., Landra, P. T. C. B., \& Samsithawrati, P. A. (2015). Penjabaran Standar Internasional TRIMs Dan OECD Dalam Ketentuan Hukum Penanaman Modal Indonesia. Jurnal Magister Hukum Udayana, 4(3), 550-564., h. 555.

2 Marceau, G. (2010). The WTO in the Emerging Energy Governance Debate. The Global Trade and Cust J, 5, 83., p. 85. 
to enforce the non-discrimination principle to investment rules in their country. The principle of MFN and NT requires the WTO member countries to give equal treatment to each investor. ${ }^{3}$

Investment activities in Indonesia are not only permitted for Indonesian citizens/legal entities but also for foreign citizens/legal entities. These domestic and foreign investors are specifically set forth in Law Number 25 of 2007 concerning Investment (hereinafter is referred to as Law No. 25/2007). Investment activities or more familiar with the term investment, according to Law No. 25/2007 is permitted to be run in various business sectors but there are also exceptions to certain business sectors. More clearly, investment activities in business sectors are classified into three namely open business sector, open with conditions for investment, and closed for investment. Regarding the sectors and types of business of those three categories above are further stipulated in the Presidential Regulation as mandated by article 12 paragraph (4) of Law No. 25/2007. In 2016, the President established Presidential Regulation No. 44 of 2016 concerning List of Closed Business Sectors and Open Business Sectors with Conditions in the Field of Investment (hereinafter is referred to as the Presidential Regulation No. 44/2016). The statute of the Presidential Regulation No. 44/2016 which was promulgated on 18 May 2016 also states revoking and annulling the Presidential Regulation No. 39 of 2014. Regulation regarding open and closed business sectors in terms of investment then becomes a reference for foreign investors regarding in which business sectors they can invest directly in Indonesia that is commonly known as a foreign direct investment (FDI). Direct investment/FDI might be a big factor influencing the economic development of Indonesia as a developing country. ${ }^{4}$

Presidential Regulation No. 44/2016 regulates the business sectors that open for investment are divided into open with the conditions of reserving business or in partnership with MSME entrepreneurs or cooperatives and open with certain conditions; namely, there is a percentage limit on the amount of foreign capital, special permits are required, restricted to certain locations, limited only to domestic capital, as well as giving more capital ownership limits in order to fulfill ASEAN cooperation with ASEAN member countries. The total amount of capital for business sectors that open to foreigners can be $100 \%$ owned by foreigners. One example of the amount of open capital with a percentage limit is open only $67 \%$ for foreigners while $33 \%$ must be owned by a domestic citizens or Indonesian legal entity. Restrictions on the open business sector, as well as the percentage of capital ownership that can be owned in Indonesia, is commonly known as the negative investment list. 5 This negative investment list then becomes a reference for investors regarding which business sectors they can invest and becomes the main key for the Investment Coordinating Board in order to issue business permits for investors.

\footnotetext{
${ }^{3}$ Santosa, A. G. D. H., Ranawijaya, I. B. E., Ariana, I. G. P., Salain, N. M. S. P. D., \& Widiatedja, I. P. (2011). Prinsip Non Diskriminasi Perjanjian General Agreement on Trade in Services (GATS) Pada Pengaturan Penanaman Modal Asing Di Bidang Pariwisata Di Indonesia. KERTHA PATRIKA, 36(2), h. 76.

${ }^{4}$ Arnold, J. M., \& Javorcik, B. S. (2009). Gifted Kids or Pushy Parents? Foreign Direct Investment and Plant Productivity in Indonesia. Journal of International Economics, 79(1), 42-53., p. 41.

${ }^{5}$ Kairupan, D. (2013). Regulation on Foreign Investment Restrictions and Nominee Practices in Indonesia. Mimbar Hukum-Fakultas Hukum Universitas Gadjah Mada, 25(2), 313-326., p. 314.
} 
Limitation of the amount of capital to be owned with respect to ASEAN is one of the requirements in the line of business sectors that open for investment. In Singapore, on 20 November 2007 the ASEAN Economic Comunity was declared at the thirteenth Summit. The concept of the ASEAN Economic Community as a unification of all ASEAN member countries is freedom of movement, of which one of them is investment activity. The ASEAN Economic Community was then agreed upon at the nineteenth Summit in Bali on 17 November 2011. Based on this cooperation, Indonesia gives privilege in the field of investment by giving higher percentage limit of the amount of capital that could be owned by foreign investors for ASEAN member countries compared with investors from Non-ASEAN countries in Presidential Regulation No. 44/2016, and even there are business sectors that are only open to investors from ASEAN member countries, which means the investment opportunities in these business sectors are closed to investors from Non-ASEAN countries.

TRIMs and GATS are two WTO agreements regarding investment arrangements, although the WTO does not yet have comprehensive regulations governing foreign direct investment. ${ }^{6}$ Ningrum in her research has an opinion that to integrate the global economy, capital invested by foreign investors is a very important factor. ${ }^{7}$ Based on Dharmawan's previous research, although it is not fully consistent with the enforcement of non-discrimination principle, this principle has been elaborated into Law No. 25/2007 as an investment rule of Indonesia, of which inconsistency is also allowed by WTO as an exception for developing countries in order to create legal harmony in the country with the requirement to provide notification of this deviation to the TRIMs board. ${ }^{8}$ In Sutanto's previous research, the discussion of the ASEAN Economic Community is not found in the WTO database as a regional trade block that is recognized for being able to deviate from non-discrimination principle. ${ }^{9}$ This paper will discuss further non-discrimination principle in foreign investment that will focus on the research problems of how the enforcement of non-discrimination principle in investment arrangements and whether the different treatment for Non-ASEAN countries contained in Presidential Regulation No. 44/2016 on the difference in the percentage limit of foreign investors' share ownership between investors from ASEAN member countries and investors from non-ASEAN countries is a violation of nondiscrimination principle. So that it is deemed necessary to be researched and set forth in written form which aims to find out about the enforcement of non-discrimination principles in investment arrangements for ASEAN and Non-ASEAN countries.

\section{Research Methods}

The target of this legal research in law or rules so that it is included in normative legal research that uses the approach of the statute and then it is examined using the legislations related to legal issues in the field of investment law and the approach of

\footnotetext{
6 Siregar, M. (2011). Hukum Penanaman Modal dalam Kerangka WTO., h.79

7 Ningrum, A. S., \& Sudiran, F. (2019). Peranan Undang-Undang Nomor 25 Tahun 2007 Tentang Penanaman Modal. LEGALITAS, 3(2), 71-89., h. 80.

8 Dharmawant, N. K. S., Landra, P. T. C. B., \& Samsithawrati, P. A. Op. Cit., h. 562.

9 Sutanto, M. C. (2015). Konsistensi Hukum World Trade Organization (WTO) Mengenai Prinsip Most Favored Nation (MFN) atas Regionalisme dan Pandangannya terhadap Asean Economic Community (AEC). Veritas et Justitia, 1(2)., p. 325.
} 
the analysis of legal concepts. This type of approach is then carried out by conducting library research on primary legal sources (legislation that is relevant to the discussion of this paper) and secondary legal sources (related books) and analyzed using description and interpretation techniques.

\section{Results and Discussion}

\subsection{Enforcement of Non-Discrimination Principle in Investment Arrangements}

Investment as a way to increase the income of Indonesia must be legally and firmly regulated considering that the balance between foreign and domestic investors is necessary. The Imbalance between foreign and domestic investors will cause both the death of small businesses and the decline of the country's economy in facing the global economy. Investment in Indonesia, by considering the economic development of the country and the balance of investment between foreign and domestic investors, has been specifically regulated in Law No. 25/2007. Investment activities can be carried out in various business sectors, but there are also exceptions to certain business sectors. To make it clear, investment regulations in Indonesia classify investment in the business sectors into three namely open business sectors, open with conditions, and closed to investment. The regulation regarding investment classification above is further stipulated in the Presidential Regulation as mandated by Law No. 25/2007 in article 12 paragraph (4).

The juridical consequence of ratification of WTO Agreements including TRIMs Agreement is the establishment of Law No. 25/2007. The establishment of the law was intended to ensure legal certainty, transparency, and equal treatment for foreign and domestic investors. The Interest of investors to invest in a country, according to Syaifuddin's research, is based on law enforcement through regulations on investment law, including the law on how to resolve investment disputes that is certain, fair and efficient. ${ }^{10}$ Indonesia as a nation of laws, also attracts investors to invest in this country by the establishment of investment regulations of Law No. 25/2007.

The clauses in the WTO agreements are stipulated by the principle of nondiscrimination of MFN and NT. MFN states that the country as the recipient of capital shall give equal treatment for foreign investors from one country and investors from other countries. The NT requires the country as a capital recipient to equalize the treatment for foreign investors and the treatment for a domestic investor. ${ }^{11}$ Regarding trade of goods, the TRIMs disallow WTO members to implementing investment policies that oppose with provisions of Article III and Article XI GATT 1994 as per NT principle. ${ }^{12}$ The Non-discrimination Principle of NT is precisely stipulated in article 2 of TRIMs. In the agreement on services trade (GATS), the MFN principle is specified in article 2 and the NT principle is stipulated in article 17.

10 Syaifuddin, M. (2011). Perspektif Global Penyelesaian Sengketa Investasi di Indonesia. De Jure: Jurnal Hukum dan Syar'iah, 3(1)., h. 61.

11 Susila, I.M. Y. D., \& Darmadi, A.A. S.W. (2015). Pengaruh Penerapan Prinsip Non Diskriminasi Penanaman Modal di Indonesia. Jurnal Fakultas Hukum Universitas Udayana, 3(03)., h. 3.

12 Putra, I. B. W., \& Dharmawan, N. K. S. (2017). Hukum Perdagangan Internasional. Bandung: PT. Refika Aditama., h. 65. 
The non-discrimination principle of MFN and NT has become the basis in the establishment of investment regulations in Law No. 25/2007 especially those that stipulated in Article3 paragraph (1) letter d that the principle of giving equal treatment and undiscriminating against the origin of the states must be the fundamental for investment activities, Article 4 paragraph (2) letter a that states the government gives the equal treatment to domestic investors and foreign investors, provides legal certainty and business certainty while still taking into account national interests, and it is also implemented in Article 6 paragraph (1), that is, Indonesia will equate attitude and behavior towards all investors from any country. In summary, according to the contents of the articles in Law No. 25/2007, it can be concluded that Indonesia as the recipient of capital has implemented the principle of non-discrimination in investment regulations in Indonesia by equalizing the treatment for every investor in carrying out investment activities, both foreign investors and domestic investors, in which national interests are still considered in its implementation and must be based on legislation. ${ }^{13}$ Fulfilling obligations for Indonesia's attachment to WTO by implementing the principle of non-discrimination of MFN and NT to national regulations in this case Law No. 25/2007, of course, must be followed by considering the national interests, this is understood for the sake of the nation's economic progress in global economic competition. The equal treatment principle in Law No. 25/2007 in Article 6 paragraph (2) stipulates the exception that equal treatment of any investor from any country can be excluded if the country has a privilege. The provisions that require to keep considering the national interests and the exemption in article 6 paragraph (2) show that the principle of non-discrimination is not fully implemented by Indonesia. ${ }^{14}$

\subsection{Different Treatment for Non-ASEAN Countries in Presidential Regulation No. 44 / 2016}

Foreign investment in Indonesia or commonly referred to as foreign direct investment (FDI) is influenced by politics in the investment destination country and institutional quality. The policies and attitudes of the government of the investment destination country are considered by foreign investors in the form of foreign citizens or companies on the plan of investment activities in the country. ${ }^{15}$ The interest of foreign investors in FDI in Indonesia is influenced by whether there is clarity in investment regulations in Indonesia, one of them is in which business sectors the foreign investors can invest as well as setting the percentage of the number of shares that can be owned by foreign investors. In addition to the clarity of the investment regulations, there are also policies that are able to attract investors, namely investment by foreign investors can be done in partnership with domestic investors and even allowed to own $100 \%$ shares in all regions of Indonesia by establishing domestic companies that include foreign investment company. ${ }^{16}$

\footnotetext{
${ }^{13}$ Susila, I.M. Y. D., \& Darmadi, A.A. S.W. Loc. Cit.

${ }^{14}$ Dharmawant, N. K. S., Landra, P. T. C. B., \& Samsithawrati, P. A. Op. Cit., h. 556.

15 Qolbi, N., \& Kurnia, A. S. (2015). Intra Asean-5 Capital Flows: Do They Represent Neoclassical Belief Or Lucas Paradox?. Buletin Ekonomi Moneter dan Perbankan, 18(2), 157-182., p. 176.

16 Safitriani, S. (2014). Perdagangan Internasional dan Foreign Direct Investment di Indonesia. Buletin Ilmiah Litbang Perdagangan, 8(1), 93-116., h.102.
} 
Type of investment based on Law No. 25/2007 classified into three. First, the business sectors that are closed, the second is open, and the third is open with conditions that must be met. The President of the Republic of Indonesia as mandated by article 12 paragraph (4) of Law No. 25/2007 established a presidential regulation to regulate business sectors in investment. President Susilo Bambang Yudhoyono during his tenure had set several presidential regulations regarding negative investment lists since 2007 which had been amended and replaced last time in 2014 with the establishment of Presidential Regulation Number 39/2014. In 2016, during the tenure of President Joko Widodo, a Presidential Regulation No. 44/2016 was established which also revoked and replaced the previous regulation, namely Presidential Regulation No. 39 of 2014. Regulations concerning open and closed businesses to investment then became a reference for foreign investors regarding which businesses they could invest directly in Indonesia. The Presidential Regulation No. 44/2016 further elaborates more clearly about investment activities in those three categories as detailed below:

1) Open business sectors are those which are not listed in the closed business sectors and open with condition business sectors;

2) Closed business sectors are those that are listed in Attachment I of Presidential Regulation No. 44/2016;

3) A Business sector that is open with conditions is those that are reserved or must be in partnership with MSME and Cooperatives. While the business sectors which open with particular circumstances are subject to limitations on the amount of capital that can be owned by foreigners, the location of certain places, allocated $100 \%$ for domestic capital (which means it cannot be owned by foreign investors), requires special permits, and limit on capital ownership related to ASEAN cooperation.

ASEAN Economic Community had been implemented since the end of 2015. On 20 November 2007, precisely at the thirteenth Summit in Singapore, the ASEAN Economic Community was declared. This is a union of ASEAN member countries using the concept of free movement of investment, capital, goods and/or services, and skilled labor. Bali Concord II, which was held in October 2003, set AEC as the aim of integration of regional economics within the grand framework of the ASEAN Vision of 2020. Tabloid Kontan No. 15 - XIX 5th edition, on 11 January 2015 based on a special study on AEC explained that there are four pillars of the objectives of the implementation of the AEC that is aimed at forming a single market and at the basis of regional production; developing areas with high competitiveness; equalizing economic development in all areas; and making ASEAN member countries an integrated region with the world class economy. ${ }^{17}$ The ASEAN Economic Community was then approved at the nineteenth ASEAN Summit on 17 November 2011 in Bali. The cooperation includes consultation on macroeconomics and financial policies; development in the field of human resources; improvements to infrastructure and communication connectivity; increase in capacity; recognition in professional qualifications; ways of financing trade; private sector involvement is enhanced;

17 Sevriana, L. (2015). Memperkuat Daya Saing Bisnis dan Ekonomi Dalam Menghadapi Asean Economic Community 2015. Jurnal Manajemen dan Bisnis: Performa, (1), 42-58., h.43. 
promoting regional resources by integrating industries in all regions; use e-ASEAN to develop electronic transactions. ${ }^{18}$

Business sectors that are open with the condition of limiting foreign capital ownership in Presidential Regulation No. 44/2016, in several business sectors contain differences in the amount of the percentage limit of capital that can be owned by foreign investors between investors from ASEAN member countries and non-ASEAN countries. The comparison is summarized as follows:

1) The forestry sector, namely enterprise activities of nature tourism in the form of services, facilities ecotourism activities in forest area including water tourism activities, natural adventure tourism, and cave tourism can be owned by foreign investors up to a maximum of $51 \%$ and for foreign investors from ASEAN member countries can have up to a maximum of $70 \%$ of capital;

2) Public works sector, namely construction services (contractor services) using high technology, high risk, work value of more than IDR 50,000,000,000, and business/construction consultancy services that use high technology, a work value of more than $\operatorname{Rp~10,000,000,000~can~be~owned~by~a~foreign~investor~at~a~maximum~}$ of $67 \%$ and for foreign investors from ASEAN member countries at a maximum of $70 \%$ of capital;

3) Tourism and Creative Economy Sector, namely museum management, travel agency, catering services, motels, houses of billiard, bowling alleys, golf courses, impresario services, organizing meetings, incentive travel, conferences, and exhibitions, can be owned by foreign investors up to $67 \%$ and investors from ASEAN member countries can have a maximum of $70 \%$ of capital. Whereas the making of promotional facilities such as films, advertisement, posters, stills, photos, slides, cliches, billboards, folders, banners, pamphlets, etc. are only allowed for foreign investors of ASEAN member countries with a maximum $51 \%$ of capital ownership;

4) Transportation Sector, namely foreign maritime for passengers, foreign maritime transport for goods can be owned by a maximum of $70 \%$ of capital by ASEAN member countries and it is closed to non-ASEAN countries;

5) Transportation Sector of discharging and loading services of goods can be owned by foreign investors at a maximum of $67 \%$ and ASEAN investors can have a maximum of $70 \%$ of capital;

6) Health Sector namely hospitals and main clinics, specialist medical clinics, specialist dental clinics, specialist nursing services, and other hospital services (medical rehabilitation clinics) can be owned by foreign investors a maximum of $67 \%$ and ASEAN investors can have a maximum of $70 \%$ of capital.

Capital ownership that can be owned by investors from the ASEAN countries above is the policy of Indonesia on the results of the implementation of the agreement between ASEAN member countries to realize the agreed aims to develop the ASEAN Economic Community. This is also regulated in Law No. 25/2007 article 6 paragraph (2) that the same treatment for every investor from any country can be excluded if the country has

18 Malau, M. T. (2014). Aspek Hukum Peraturan Dan Kebijakan Pemerintah Indonesia Menghadapi Liberalisasi Ekonomi Regional: Masyarakat Ekonomi Asean 2015. Jurnal Rechts Vinding: Media Pembinaan Hukum Nasional, 3(2), 163-182., h.165. 
privilege based on an agreement with Indonesia one of which relates to the agreement between Indonesia and a regional foreign country in this case ASEAN. ${ }^{19}$ It is understood that the difference is the result of the policy of Indonesia in relation to Indonesia's membership in ASEAN to provide privileges for ASEAN members in terms of investments in several business sectors.

Indonesia which is a member of ASEAN certainly has an obligation to fulfill the aims of developing the ASEAN economic community, but on the other hand, Indonesia is also a member of WTO so it is bound by agreements on world trade, one of which is the TRIMs Agreement as an agreement on investment policy. WTO agreements adhere to the principle of non-discrimination, namely MFN and NT. Indonesia as a WTO member country, in this case, is obliged to comply with international trade standards by applying the non-discrimination principles namely MFN and NT as referred to in the article 2 of TRIMs, and article 2 and article 17 of GATS, but developing countries and underdeveloped countries are still given an exception by WTO to specifically regulate important policies relating to the needs of the country in the development of international trade..$^{20}$ The exception emphasizes that the same treatment can be given by prioritizing the national interests of the country concerned as regulated in article 4 of the TRIMs. According to article 4 of TRIMs, developing countries are given an exception by allowing developing countries, at any time and temporarily, to diverge from the provision of article 2 of TRIMS agreement insofar as it is related to the implementation of the provisions of Article XVIII of GATT 1994. ${ }^{21}$ Article XVII of GATT 1994 states that policies of a developing country can be enforced as long as it supports the living standards of the people of the member country. ${ }^{22}$ This policy can certainly be enforced with the requirement to give notification to the Council on Goods Trade. ${ }^{23}$ The notification is further regulated in article 5 of TRIMS, that all WTO members are given a 90-day period from the commencement of the WTO agreements to notify on their regulations that are not in accordance with TRIMS and for developing countries, in this case, Indonesia is given 7 years period for the transitional phase of the abolition of TRIMS that is not appropriate and can extend the transitional phase by submitting an application to the Council on Goods Trade by explaining the reasons of the difficulties faced in implementing TRIMS. ${ }^{24}$ Indonesia and other ASEAN member countries as developing countries are included in the criteria as referred to in article 4 of the TRIMs so that they can deviate from the provisions in article 2 of the TRIMs. The enforcement of the non-discrimination principle in GATS can also be deviated as "Annex on Article II Exemptions" by including the provisions in specific of commitment which can be valid for up to 10 years and will be reviewed every 5

19 Rohendi, A. (2014). Prinsip Liberalisasi Perdagangan World Trade Organization (WTO) Dalam Pembaharuan Hukum Investasi Di Indonesia (Undang-Undang Nomor 25 Tahun 2007) (Principle of Trade Liberalization of World Trade Organization (WTO) in Reforming the Investment Law of Indonesia (Indonesian Law No. 25 of 2007)). Padjadjaran Jurnal Ilmu Hukum, 1(2)., h. 9.

${ }^{20}$ Dharmawan, N. K. S. (2014). Keberadaan dan Implikasi Prinsip Mfn dan Nt dalam Pengaturan Hak Kekayaan Intelektual di Indonesia. Jurnal Magister Hukum Udayana (Udayana Master Law Journal), 3(2), h. 260.

${ }^{21}$ Putra, I. B. W., \& Dharmawan, N. K. S. Op Cit., h. 66.

22 Ibid., p. 59.

${ }^{23}$ https://wwww.wto.org/english/docs_e/legal_e/18-trims_e.htm\#ann. (Diakses 14 Mei 2019).

${ }^{24}$ Dharmawant, N. K. S., Landra, P. T. C. B., \& Samsithawrati, P. A. Op. Cit., h. 561. 
years. ${ }^{25}$ Flexibility regarding the obligations of a developing country is also regulated in article IV of GATS, that is developing countries, in their participation, are given convenience through negotiation on specific of commitment with other countries in terms of increasing efficiency and competitiveness of the domestic service sector by the access to commercial technology, increasing access to distribution channels and networks information, and market access liberalization. Furthermore, article V of GATS stipulates that each member country can enter into a liberalization agreement on services trade with other countries provided that the agreement must cover many sectors and it is not discriminative. In that article, precisely paragraph 3 subparagraph (a) developing countries are given the flexibility to meet the conditions previously outlined by considering the level of development of the country. A country that enters into an agreement with another country shall have an obligation to provide notification of the agreement enforcement to the Council of Services Trade. ${ }^{26}$ Besides that WTO's treatment for developing countries also includes implementation of gradual liberalization or what is called the Progressive Liberalization principle so that Indonesia can determine the extent of its attachment to the enforcement of the nondiscrimination principle. ${ }^{27}$

Normalizing the percentage limits of capital ownership between investors from ASEAN countries and non-ASEAN countries in Presidential Regulation No. 44/2016 does not mean that Indonesia is not compliant in fulfilling its obligations as a member of WTO but rather is a policy that is carried out in the context of Indonesia's membership in ASEAN. Indonesia as a developing country is included in the exception by WTO so that it can make regulations in this case specifying privilege to ASEAN member countries, namely Malaysia, Philippines, Brunei Darussalam, Thailand, Cambodia, Laos, Myanmar, Singapore, and Vietnam. The privilege given is also based on Indonesia's cooperation with ASEAN countries which are also developing countries with the aim of maximizing the competitiveness and economic development of the ASEAN community. Limitation on the percentage of foreign capital ownership in Presidential Regulation No. 44/2016 only includes several business sectors which of course this limitation has taken into account the fulfillment of Indonesia's obligations as an ASEAN member country on the one hand and a WTO member country on the other hand.

\section{Conclusion}

The principle of non-discrimination of MFN and NT has been implemented by the establishment of regulations regarding investment in Indonesia, especially Law No. $25 / 2007$. The non-discrimination principle is clearly implemented in article 3 paragraph (1) letter $d$, article 4 paragraph (2) letter a, and article 6 paragraph (1) of Law No. 25/2007, although this principle is not fully implemented considering that there is a provision requiring to keep considering the national interests in article 4 paragraph (2) letter a and exceptions to countries that have privilege in article 6 paragraph (2).

\footnotetext{
${ }^{25}$ Siregar, M. Op Cit., h.13.

${ }^{26}$ Putra, I. B. W., \& Dharmawan, N. K. S. Op Cit., h. 92.

27 Yanti, A. A. I. E. K. (2018). Prinsip Non Diskriminasi Tenaga Kerja Asing Dalam Kerangka GATS: Dimensi Kepariwisataan. Jurnal Magister Hukum Udayana (Udayana Master Law Journal), 7(2), 190-203., h. 201.
} 
The implementation of the non-discrimination principle shows that Indonesia has fulfilled its obligations as a member of WTO to comply with international trade standards.

Article 4 of TRIMs agreement gives exceptions and enables the developing countries at any time and temporarily to deviate from the provision of article 2 regarding the nondiscrimination principle insofar as it is related to the implementation of the provisions of Article XVIII of GATT 1994 and with the requirement to notify the Council on Goods Trade. Developing countries are also given convenience by GATS as article IV, that is developing countries, in their participation, are given convenience through negotiation on specific of commitment and given the flexibility of implementing the principle of non-discrimination in entering into trade liberalization agreement on services trade with other countries as Article V of GATS by providing notification of the implementation of the agreement to the Council of Trade in Services. The difference in the percentage of foreign capital ownership limit that can be owned by foreign investors from ASEAN member countries and from Non-ASEAN countries in Presidential Regulation No. 44/2016 is not a violation of the non-discrimination principle considering that Indonesia as a developing country is exempted from article 4 of TRIMs agreement to deviate from the rules of article 2 of TRIMs, and the flexibility to implementing non-discrimination principle as articles 4 and 5 of GATS.

\section{References}

$\underline{\text { Books }}$

Putra, I. B. W., \& Dharmawan, N. K. S. (2017). Hukum Perdagangan Internasional. Bandung: PT. Refika Aditama.

Siregar, M. (2011). Hukum Penanaman Modal dalam Kerangka WTO.

\section{Journals}

Arnold, J. M., \& Javorcik, B. S. (2009). Gifted Kids or Pushy Parents? Foreign Direct Investment and Plant Productivity in Indonesia. Journal of International Economics, 79(1), 42-53. https://doi.org/10.1016/j.jinteco.2009.05.004

Dharmawan, N. K. S. (2014). Keberadaan dan Implikasi Prinsip MFN dan NT Dalam Pengaturan Hak Kekayaan Intelektual di Indonesia. Jurnal Magister Hukum Udayana (Udayana Master Law Journal), 3(2), 44117. https://doi.org/10.24843/JMHU.2014.v03.i02.p03

Dharmawant, N. K. S., Landra, P. T. C. B., \& Samsithawrati, P. A. (2015). Penjabaran Standar Internasional TRIMs Dan OECD Dalam Ketentuan Hukum Penanaman Modal Indonesia. Jurnal Magister Hukum Udayana, 4(3), 550-564. https://doi.org/10.24843/JMHU.2015.v04.i03.p11

Kairupan, D. (2013). Regulation on Foreign Investment Restrictions and Nominee Practices in Indonesia. Mimbar Hukum-Fakultas Hukum Universitas Gadjah Mada, 25(2), 313-326. https:// doi.org/10.22146/jmh.16087

Malau, M. T. (2014). Aspek Hukum Peraturan Dan Kebijakan Pemerintah Indonesia Menghadapi Liberalisasi Ekonomi Regional: Masyarakat Ekonomi Asean 2015. Jurnal Rechts Vinding: Media Pembinaan Hukum Nasional, 3(2), 163-182.

Marceau, G. (2010). The WTO in the Emerging Energy Governance Debate. The Global Trade and Cust J, 5, 83. 
Ningrum, A. S., \& Sudiran, F. (2019). Peranan Undang-Undang Nomor 25 Tahun 2007 Tentang Penanaman Modal. LEGALITAS, 3(2), 71-89. https://doi.org/10.31293/lg.v3i2.4100

Qolbi, N., \& Kurnia, A. S. (2015). Intra Asean-5 Capital Flows: Do They Represent Neoclassical Belief Or Lucas Paradox?.Buletin Ekonomi Moneter dan Perbankan, 18(2), 157-182. https://doi.org/10.21098/bemp.v18i2.521

Rohendi, A. (2014). Prinsip Liberalisasi Perdagangan World Trade Organization (WTO) Dalam Pembaharuan Hukum Investasi Di Indonesia (Undang-Undang Nomor 25 Tahun 2007) (Principle of Trade Liberalization of World Trade Organization (WTO) in Reforming the Investment Law of Indonesia (Indonesian Law No. 25 of 2007)). Padjadjaran Jurnal Ilmu Hukum, 1(2).

Safitriani, S. (2014). Perdagangan Internasional dan Foreign Direct Investment di Indonesia. Buletin Ilmiah Litbang Perdagangan, 8(1), 93-116. https://doi.org/10.30908/bilp.v8i1.89

Sevriana, L. (2015). Memperkuat Daya Saing Bisnis dan Ekonomi Dalam Menghadapi Asean Economic Community 2015. Jurnal Manajemen dan Bisnis: Performa, (1), 42-58. https:// doi.org/10.29313/performa.v0i1.3042

Susila, I.M. Y. D., \& Darmadi, A.A. S.W. (2015). Pengaruh Penerapan Prinsip Non Diskriminasi Penanaman Modal di Indonesia. Jurnal Fakultas Hukum Universitas Udayana, 3(03).

Sutanto, M. C. (2015). Konsistensi Hukum World Trade Organization (WTO) Mengenai Prinsip Most Favored Nation (MFN) atas Regionalisme dan Pandangannya terhadap Asean Economic Community (AEC). Veritas et Justitia, 1(2). https://doi.org/10.25123/vej.1690

Syaifuddin, M. (2011). Perspektif Global Penyelesaian Sengketa Investasi di Indonesia. De Jure: Jurnal Hukum dan Syar'iah, 3(1). https://doi.org/10.18860/jfsh.v3i1.1320

Yanti, A. A. I. E. K. (2018). Prinsip Non Diskriminasi Tenaga Kerja Asing Dalam Kerangka GATS: Dimensi Kepariwisataan. Jurnal Magister Hukum Udayana (Udayana Master Law Journal), 7(2), 190-203. https://doi.org/10.24843/JMHU.2018.v07.i02.p05

\section{Website}

World Trade Organization. Agreement on Trade-Related Investment Measures. Retrieved from https://www.wto.org/english/docs_e/legal_e/18-trims_e.htm 